\title{
PRELEMINARY ANALYSIS OF CAUSE-EFFECT ON FOREST- PEATLAND FIRES PRIOR TO 2020 IN CENTRAL KALIMANTAN
}

\author{
Nina Yulianti ${ }^{12 *}$, Kitso Kusin ${ }^{23)}$, Elvi Murni ${ }^{3)}$, Dedy ${ }^{3)}$, Betrixia Barbara ${ }^{1)}$, Daisuke \\ Naito $^{4567)}$, Osamu Kozan ${ }^{56)}$, Yusurum Jagau ${ }^{123)}$, Ici Piter Kulu ${ }^{13)}$, Fengky Florante Adji ${ }^{13)}$, \\ Kurniawan Eko Susetyo ${ }^{7)}$ \\ ${ }^{1)}$ Faculty of Agriculture, University of Palangka Raya, Palangka Raya, Indonesia \\ ${ }^{2)}$ Graduate Program of Environmental Science, University of Palangka Raya, Palangka Raya, Indonesia \\ ${ }^{3)}$ UPT. LLG - CIMTROP, University of Palangka Raya, Palangka Raya, Indonesia \\ ${ }^{4)}$ Faculty of Agriculture, Kyoto University, Kyoto, Japan \\ ${ }^{5)}$ CSEAS, Kyoto University, Kyoto, Japan \\ ${ }^{6}$ Research Institute for Humanity and Nature (RIHN), Kyoto, Japan \\ ${ }^{7)}$ Center for International Forestry Research (CIFOR), Bogor, Indonesia \\ *Email: nyulianti@agr.upr.ac.id
}

\begin{abstract}
Central Kalimantan covers an area of $157,983 \mathrm{~km}^{2}$ with more than 2,000 $\mathrm{km}^{2}$ of tropical peatlands, which is one of the buffer regions of Indonesia's new capital government city. However, the sad story is the conversion of about one million hectares from peat swamp forests (PSF) to rice fields occurred in the mid-1990s, so called the Mega Rice Project (MRP). Since then, forest and peatland fires become an annual event due to high level of degradation under the climate change symptoms such the frequent of the El Niño event. In very strong El Niño of 2015, Indonesia has returned to the world spotlight in relation to the fires and the haze crisis. The most fire prone area was recorded in the iconic Tumbang Nusa, Pulang Pisau Regency and its adjecent areas. However, the thick haze had covered almost the entire province. There are the dis-adventages impact during more than two months. Therefore, this study was to investigate what are the causes and the impacts of this disaster at the site level. This research location was focuses on three regencies and one city namely Pulang Pisau, Kapuas, Katingan and Palangka City. The method was a Focus Group Discussion (FGD) with key figures representing eight clusters of village communities. This method is also supported by statistical, hotspots and spatial data for additional analysis. The result are only two villages with very high average of hotspot and eight with high average of hotspots in Pulang Pisau and Kapuas Regency. Further, the FGDs in seven villages showed that there were three main clusters that caused forest-land fires, namely natural factors, human factors and village policy / regulation factors. The villages study that were affected by the fire in 2015 showed there were three main impacts namely on people, environment and capital. This result is a foundation of cause-effect factor for further Root Cause Analysis to find out the options for fire prevention and management in climate change mitigation efforts.
\end{abstract}

Keywords: Climate Change; El-Niño; Fires; Focus Group Discussion; Peatland

\section{INTRODUCTION}

Since the very strong El Niño event in 1997/1998, Kalimantan has always been the object of annual forest-peatland fires. Approximately half of the numbers of total hotspots in Indonesia are in Kalimantan. An area of Central Kalimantan Province holds the first rank among five provinces (Yulianti et al., 2012). Hotspot maps in Kalimantan show that most fire-prone areas are covering the peatlands, especially in Central, South and West Kalimantan (Yulianti \& Hayasaka, 2013). The conversion of forest functions and the massive degradation of peatland during the previous decades could be a factor behind the incident. These widespread forestpeatland fires have serious negative impacts 
on various sectors ranging from local to global levels (Limin et al, 2007; Yulianti, 2011; WBG, 2016). Officially, Indonesia accepts the position as one of the largest global carbon emitter countries (DNPI, 2011) and the exporter of transboundary-haze pollution for Southeast Asian countries (Heil et al., 2006).

In 2014/2015, this frightening condition reoccurred under the influence of the El Niño event, too. Endarwati (2016) stated that the distribution of forest-land fires in 2015 was mostly found in the other use areas outside the forest, where those areas close to the community access. As many as $22 \%$ of the total fires occurred on peatlands. It seemed the non-forest fire spread out to conservation swamp forests such in Sebangau and Tanjung Putting National Park in Central Kalimantan. Indications of the distribution of fire areas on peatlands in Central Kalimantan Province are over 500.000 ha. This condition generates the worst air pollution in history for the last decade (Hayasaka and Sepriando, 2018). The haze is not only releases greenhouse gases but also contains harmful gases for humans (Stockwell et al 2017; Wooster et al, 2018). Air quality in 2015 exceeding the safe limit for human and living things. The previous study predicted tens of thousands of people are exposed to respiratory diseases, many flights were canceled, and schools were closed during the peak fire season. There were indications of haze had blowing to neighboring Southeast Asian countries and polluting air quality in neighboring Singapore and Malaysia (Van Mead, 2017; Ramakreshnan et al 2017; Koplitz et al, 2016).

The other studies with spatial methods and literature reviews try to explore what the causes behind the fire occurrences (Atwood, 2016; Sumarga, 2017; Carlson, 2017; Hirschberger, 2017) and also how the impacts
(Koplitz et al., 2016; Yulianti, 2018 Marlier et al, 2019; Uda et al. 2019;) of the forestpeatland fires in the modern situation. However, it turns out that the forest-peatland could not stop after 2015, and even continues today. There are indications that the causes and impacts also vary depending on geographical, social, economic, cultural and local political issues from year to year. According to Ferdinand (2006), this type of causality research is research conducted to look for an explanation of the cause-effect relationship or cause-effect between several variables in a management goal, which can also be a means of finding options for a problem. Jua'rez-Orozco et al (2017) and Lestari et al (2018) conduct research on the impacts and causes of tropical forest fires with a bibliometric and knowledge-based approach. This study seeks to investigate what conditions and parameters at the site level with various categories of forest-fire and haze hazard in Central Kalimantan using social research methods. This research aims to found effective ways in the prevention and mitigation of future forest-peatland fires.

\section{METHODOLOGY}

\subsection{Research Location}

The locations of this study are several villages in Palangka Raya City, Pulang Pisau, Kapuas and Katingan Regencies in Central Kalimantan Province as shown in Figure 1. The coordinates of the study sites include $0^{\circ} 24^{\prime}$ to $3^{\circ} 22^{\prime}$ South Latitude and $112^{\circ} 06$ ' to $114^{\circ} 45$ East Longitude. The research began in 2018 and is planned until 2020, which it can cover various categories of forest-peatland fire and haze hazard in Central Kalimantan (Table 1). However, the results in this article shown are only for 2 (two) years, excluding the 2020 activity. 
Table 1. Villages in Research Location

\begin{tabular}{lll}
\hline Year of 2018 & Year of 2019 & $\begin{array}{l}\text { Year of 2020* } \\
\text { [rencana] }\end{array}$ \\
\hline $\begin{array}{l}\text { 1.Tumbang Nusa, Pulang } \\
\text { Pisau acf }\end{array}$ & $\begin{array}{l}\text { 3. Tanjung Taruna, Pulang } \\
\text { Pisau acf }\end{array}$ & 8. Bahaur, Pulang Pisau ${ }^{\text {abf }}$ \\
2. Buntoi, Pulang Pisau & $\begin{array}{l}\text { 4. Kalampangan, Palangka } \\
\text { Raya aef }\end{array}$ & 9. Baun Bango, Katingan $^{\text {df }}$ \\
& $\begin{array}{l}\text { 5. Kereng Bangkirai, } \\
\text { Palangka Raya adf }\end{array}$ & 10. Mandomai, Kapuas $^{\text {ef }}$ \\
& $\begin{array}{l}\text { 6. Luwuk Kanan, Katingan adf } \\
\text { 7. Bukit Tunggal, Palangka } \\
\text { Raya adf }\end{array}$ & \\
\hline
\end{tabular}

Note:

a. Priority of peat restoration area post 2015 fire from Figure 2

b. Average of very high hotspot area from table 2

c. Average of high hotspot area from table 2

d. Average of moderate hotspot area from table 2

e. Average of low hotspot area from table 2

f. Location in peatlads

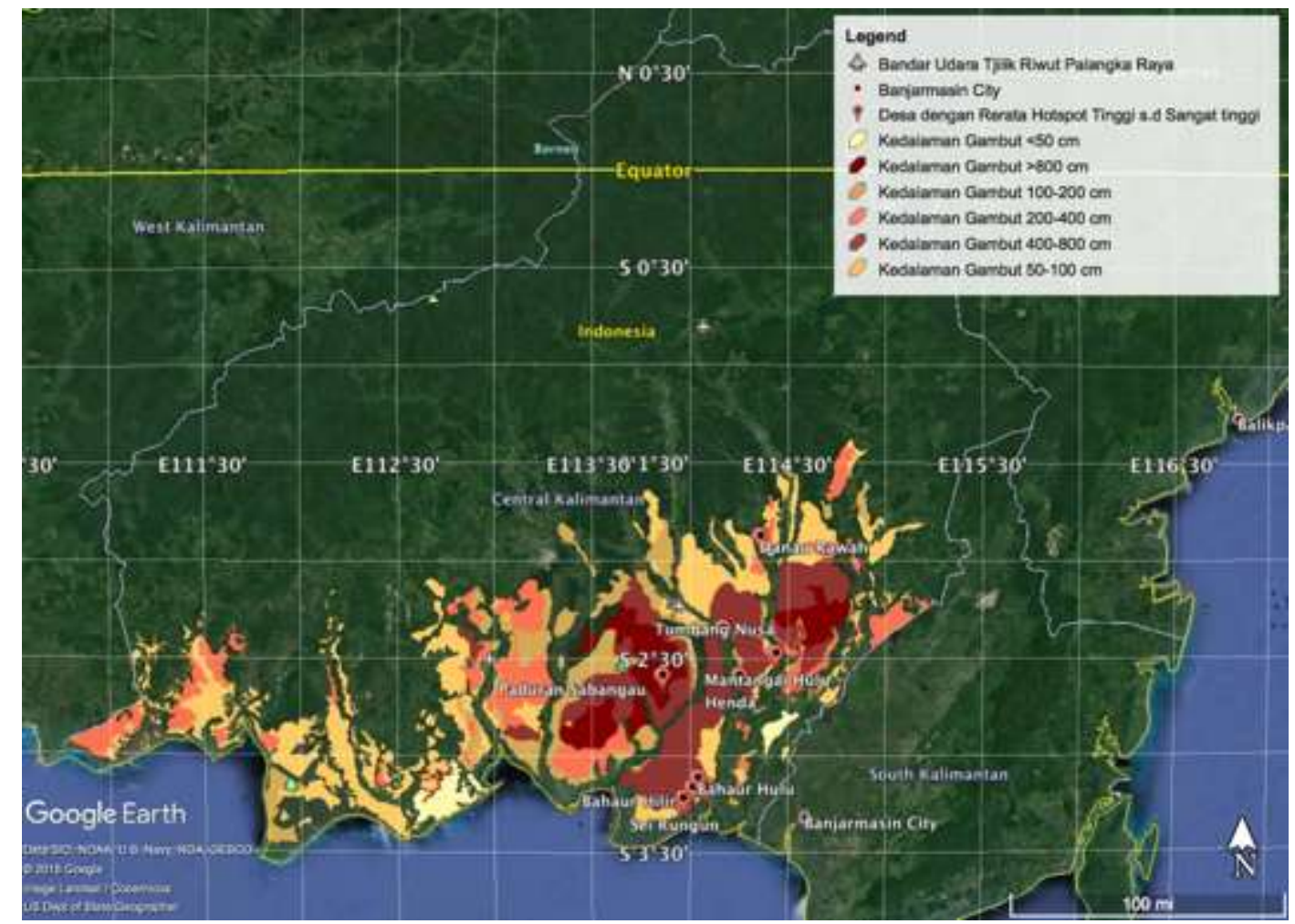

Figure 1. Peatland distribution in Central Kalimantan, Indonesia

(Note: kedalaman gambut is depth peat; desa is village; bandar udara is airport) 


\subsection{Methods and Data Analysis}

In social survey research, the way of calculating the large research samples is determined by the research design used and the data taken. This study uses the Slovin formula to calculate sample sizes. This formula was introduced by Slovin in 1960 and often used in survey research with a large number of samples, so we need the formula to get a small sample but can represent the entire population (Altares et al 2003). The equation used is:

$$
\mathrm{n}=\mathrm{N} /\left(1+\left(\mathrm{N} \mathrm{x} \mathrm{e}^{2}\right)\right)
$$

Which:

\section{n : Total Sample}

$\mathrm{N}$ : Total Population

e : Tolerance percentage of sampling error (10\% as in Loren et al, 2015)

The number of the adult population in the villages (groups of 20 years and over) who are considered to be able to express their opinions independently in FGD activities is 585,758 people, where spread in 4 (four) districts (Table 2). This study uses a $90 \%$ degree of confidence, the error rate is $10 \%$. Researchers can determine what is the minimum limit of samples that can meet the requirements of an error rate of $10 \%$ by entering these numbers into Slovin formula. This greater value is due to the consideration of the large diversity of conditions in the research location and FGD facilitators. The results of the calculation of sampling are obtained at least 100 people as respondents in this study, where each village was divided as many as 20 respondents.

The data collection method is the most strategic step in qualitative and quantitative research because the main objective of the study is to obtain data in several ways such as in this study, namely:
1. Focus Group Discussion (FGD) is where the researcher conducted a question and answer method with 8 (eight community groups), namely village officers, traditional and religious leaders, community firefighter, farmers and fishermen groups, women's groups, youth groups, representatives of teachers, and representatives of health workers.

2. Observation is where researchers review the location of fires at several points during the fire season. The results of these observations will be directly noted by researchers so that from this activity can be known how the causal process of forest fires.

3. Study of bibliography and statistical data collection from the Indonesia Statistical Agency, Provincial Disaster Agency and local village profiles

The data analysis technique used was to categorize the various causes and impacts of fires delivered by respondents in focus group discussions on the village that was the location of the study. In this research, indepth analysis has not been carried out such as the Fishbone diagram or Ishikawa Diagram often also called fishbone diagram-because of its shape like fish bones. The reason is that this research is still preliminary mapping of the main causes and impacts, which the results only display tabular forms.

\section{RESULTS AND DISCUSSION}

\subsection{The Fire-Prone Areas}

The number of villages that were targeted in this study was 444 , based on the initial map of district division in 2002. There is a possibility that the number of new villages could increase in 2019 . The districts with the most villages are Kapuas Regency and the least is Palangka Raya City. Table 2 shows that around $80 \%$ of the villages in the four regencies recorded historically had one 
or more hotspots. 2 villages are categorized as very high, 8 villages that are categorized as high, 70 villages are classified as moderate and the rest are only low. The villages with very high and high categories are in Pulang Pisau and Kapuas Regencies. Figure 1 shows that the majority of these villages are on peatlands.

The number of hotspots shown in Table 2 is not the actual number of fires in the field. The main reason is that a pixel hotspot is within a radius of $1 \mathrm{~km}^{2}$ and can be $500 \mathrm{~m}^{2}$ if the weather is good (Giglio et al, 2003), so those small fire incidents are often not detected. Especially in this study, the data selected were those that had a more $60 \%$ confidence level. Besides, TERRA and AQUA satellite sensors recorded only cross an area at a certain time, which can be when severe fires are not detected. Hotspot locations also cross administrative boundaries so it is very difficult to analyze them, for example, hotspot pixel coordinates in Village A but within a $1 \mathrm{~km}^{2}$ pixel radius including in Village B. Thus, hotspots are only an indicator that an area is prone or does not experience forest fires such as in previous studies from Yulianti et al (2013). This parameter can also be used to overcome the limitations of observing and recording the data from field-workers.

Table 2. Average of Hotspot Category from 2006 to 2018.

\begin{tabular}{|c|c|c|c|c|c|c|c|c|}
\hline \multirow[b]{2}{*}{ Regency } & \multirow[b]{2}{*}{$\begin{array}{l}\text { Total } \\
\text { Area } \\
\left(\mathbf{k m}^{2}\right)\end{array}$} & \multirow{2}{*}{$\begin{array}{l}\text { Adult } \\
\text { Popul } \\
\text { ation* }\end{array}$} & \multicolumn{5}{|c|}{ Average of Hotspot Category } & \multirow[b]{2}{*}{$\begin{array}{c}\text { Total of } \\
\text { Village }^{* * *}\end{array}$} \\
\hline & & & $\begin{array}{l}\text { Very } \\
\text { High } \\
(>100 \\
)\end{array}$ & $\begin{array}{l}\text { High } \\
(51-100)\end{array}$ & $\begin{array}{l}\text { Moderate } \\
(11 \text { - 50) }\end{array}$ & $\begin{array}{l}\text { Low } \\
(1-10)\end{array}$ & $\begin{array}{l}\text { No } \\
\text { Fire } \\
\text { (0) }\end{array}$ & \\
\hline Pulang & & & & & & & & \\
\hline Pisau & 8997 & 81228 & 2 & 6 & 20 & 47 & 6 & 81 \\
\hline Kapuas & 14999 & $\begin{array}{l}222 \\
200\end{array}$ & & 2 & 20 & 116 & 40 & 178 \\
\hline $\begin{array}{l}\text { Palangka } \\
\text { Raya }\end{array}$ & 2399 & $\begin{array}{l}179 \\
782\end{array}$ & & & 8 & 17 & 5 & 30 \\
\hline Katingan & 17500 & $\begin{array}{l}102 \\
548\end{array}$ & & & 22 & 104 & 29 & 155 \\
\hline Total & 43895 & $\begin{array}{l}585 \\
758\end{array}$ & 2 & 8 & 70 & 284 & 80 & 444 \\
\hline
\end{tabular}

Note:

*Census data in 2017

**Based on administration map in 2002

Based on simultaneous research on Yulianti et al (2019), forest-peatland fires in 2015 were the worst events in history in the 21 st century. The epicenter distribution of the most vulnerable areas is Pulang Pisau, Kapuas, Katingan and Palangka Raya cities. Large numbers of forests and peatlands burned uncontrollably, reaching their peak in September and October 2015. In these months the type of fire that occurred was an underground fire (smoldering). According to Yulianti (2018), fuel from this type of fire is not only littering on the surface of the peat but also the layer of dry peat reaching tens of 
centimeters. The firefighting team is very difficult to detect this type of fire because there is often no visible flame or smoke release. Figure 2 shows the results of the analysis of the distribution of former fires and hotspots in 2015 for priority restoration in
Central Kalimantan. The total area is 8000 $\mathrm{km}^{2}$ or greater than Bali Island which is only $5000 \mathrm{~km}^{2}$. This figure shows how much the loss of peatlands as a carbon source and climate balancer.

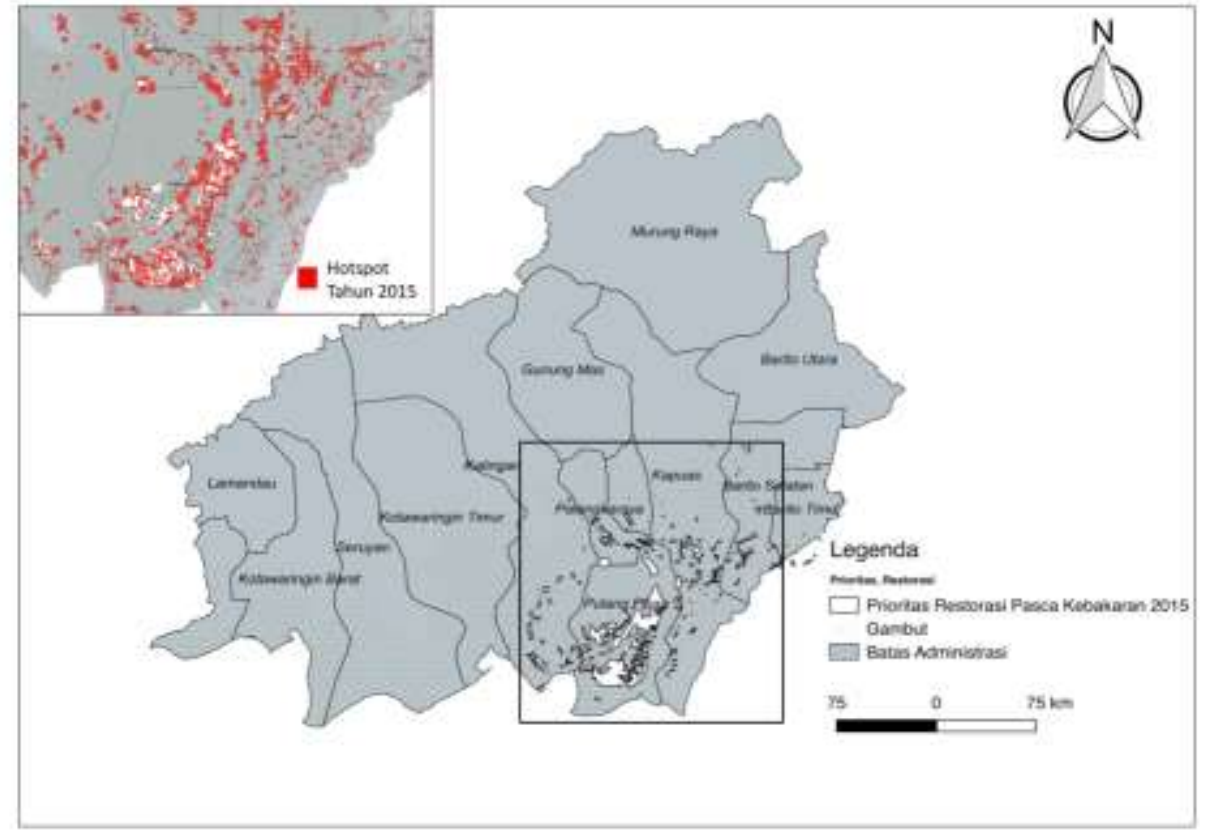

Figure 2. Priority of peat restoration area post 2015 fire (white color) and the hotspot distribution in 2015 (red dot color) for EMRP areas

Since then, the Indonesian Government has become more stringent in managing peatlands through various policies such as the following: 1) carrying out a peatland restoration program by establishing a Peat Restoration Agency (abbrv. BRG), issuing a moratorium map on peatland use permits through the Ministry of Environment and Forestry (Abbrv. KLHK) and taking firm action against perpetrators of forest and land burning through the Letter of Republic of Indonesia Police (Abbrv. POLRI) as mentioned in Yulianti (2018). Peatland restoration was carried out on 2015's burned peatlands in seven priority provinces in Indonesia, one of which was Central Kalimantan (Figure 2). Some companies in Central Kalimantan are suspended or revoked to obtain permits if they are located on the peatlands (Anonymous, 2016). The Central Kalimantan Regional Police are reported to have handled almost 200 cases of forest fires during 2019. Of these, approximately 150 cases are still under investigation and around 30 cases have reached the investigation stage Even dozens of people suspected of being perpetrators of land burning both individuals and corporations have also been secured during the post-2015 forest fires (Priyono, 2019).

\subsection{Cluster of Main Causes}

The starting point of this research is the very severe forest-fire in 2015, although in 2018 it was also recorded as the top 10 fires in Central Kalimantan (Yulianti et al., 2019). Based on the results of the FGD and observations there are 3 (three) main causes of forest-fire clusters as listed in Table 3. Factors in the first and second columns are the answers of the majority of respondents, while the third column is the result of answers from the respondent, especially those located 
in Palangka Raya City (Figure 3). Each village has a specific cause. For example, from respondents in Desa Tumbang Nusa, Pulang Pisau obtained an answer that the main factor in the fires that spread was accidental/negligence such as littering cigarette butts or uncontrolled burning, especially in abandoned areas around the Primary Channel (abbrv. SPI) which is located between the trans- Kalimantan and Sebangau River. Meanwhile, one of the causes such in Kelurahan Bukit Tunggal. There is an intentional for political-related sabotage related to provincial or city elections schedule.

Previous research in several regencies in Central Kalimantan by Barbara et al.
(2015) shows that approximately 70 percent of respondents practice clear land by burning until the middle of 2015 . This condition has great potential as a major cause of fire and haze crisis. Whereas, this study is not defined as the causes by percentage but the combination of the cluster of main factors and its sub-factors. For example, scenario 1 is the land burning carried in non-El Niño years, scenario 2 is the El Niño phenomenon occurred but the burning is not in the peatlands, scenario 3 is there is lack of regulation for prohibiting burning at the village level but the peatland is still waterlogged or natural condition. The scenarios might support a little chance of massive forest-peatland fires such as 2015 or 2019.

Table 3. Analysis of main causes of forest and peatland fire in 2015

\section{Natural causes of fire}

El Niño phenomenon (every 2-15 years)

Land damaged / unsuitable for planting

Land left abandoned or bare

\section{Human cause of fire}

Clearing land for economic activity

Fishing

Throwing away cigarette butts

Burning trash

Accident / failure

\section{Factors affecting policy}

Lack of regulations prohibiting burning at the village level

Lack of village-level regulations regarding burning peatland as a

land management practice

Lack of village-level regulations on this front National conservation efforts, relocation of the capital, expansion of rice fields, and transmigration

The policy regarding to the national and regional election schedule, for example the severest fire in 2015 coincided with the election of the Governor of Central Kalimantan or the fires of 2019 coincided with the presidential election. 

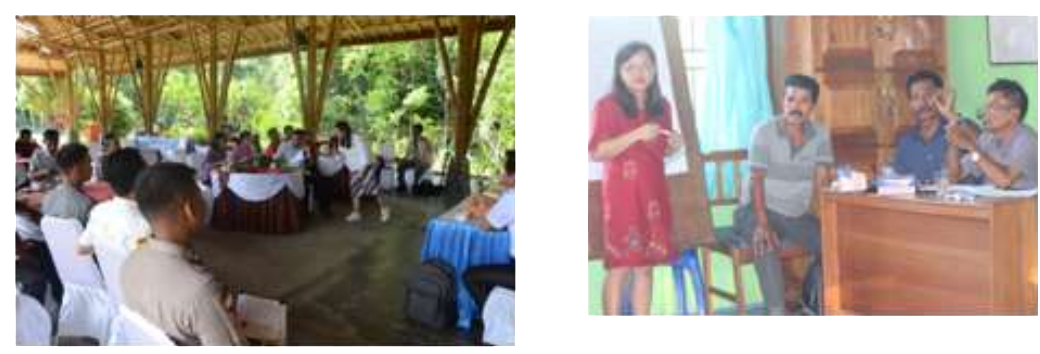

Buntoi, Pulang Pisau on 5 September 2018 (MAFF 2018)

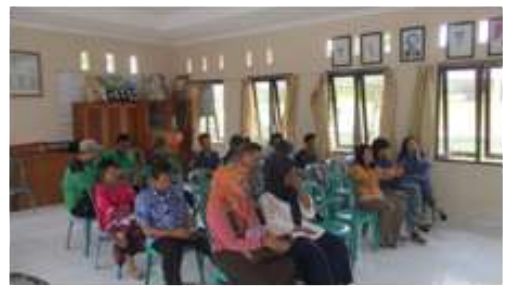

Kereng Bangkirai, Palangka Raya on 11 April 2019 (RIHN, 2019)
Tumbang Nusa, Pulang Pisau on 7 Sept 2018 (MAFF 2018)

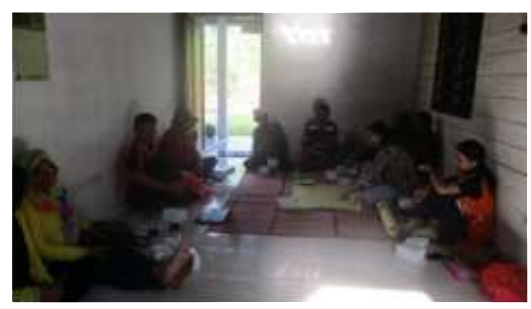

Kalampangan, Palangka Raya on 12 April 2019 (RIHN, 2019)

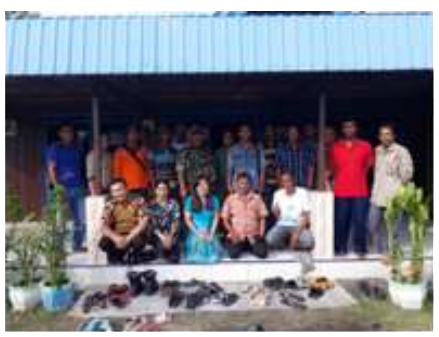

Tanjung Taruna, Pulang Pisau on 28 Maret 2019 (RIHN, 2019)

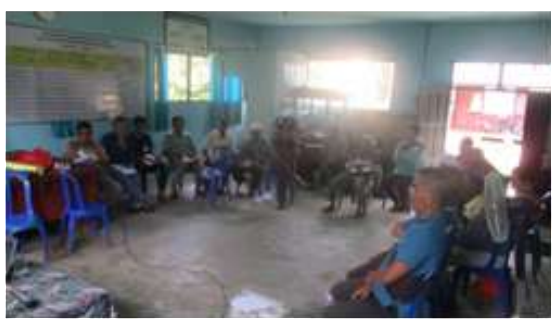

Luwuk Kanan, Katingan on 13 April 2019 (MAFF, 2019)

Figure 3. Activity of FGD in villages of Pulang Pisau Regency and Palangka Raya City

\subsection{Cluster of Main Impact}

As same as in section 3.2, the impact of forest-land fires referred to in this study began in 2015. There are 3 (three) clusters of impacts experienced by respondents who were in the village as the research location as listed in Table 4. The direct impact that was felt shortly after the incident was to humans and living things. When the thick haze releases from the peat fire is concentrated in the areas, it will cause a variety of disadvantages to health, livelihoods and quality of education. The impact on the environment can be observed after a few days or weeks of fire, such as shrinking peat, hot temperatures, reduction or depletion of forest products and non-forest products, contamination on air, water and soil. Further, the worse forest-peatland fires could impact on the gardens / land come on fire, the house also catches fire and also public facilities are disturbed. However, this study has not calculated the economic value of the impacts in Table 4.

Some impact factors and sub-factors are still in line with previous research although using a different approach that conducted by Limin et al (2007), Yustiawati et al (2016), Uda et al (2018). One of the macro-scale studies such conducted by the World Bank Group stated that the cost of forest fires in Indonesia in 2015 reached US \$ 16 billion (WBG, 2016). Meanwhile, the decline in income due to the impact of the household level on the livelihoods of fishermen and rubber farmers in several villages in Pulang Pisau Regency ranged from 20\% to $40 \%$ (Yulianti et al, 2015). 
Table 4. Analysis of main impacts of forest and peatland fire in 2015

\section{Impact on Human}

Human health [ URI, stomach ache, miscarriage, death]

Difficult livelihoods [due to disrupted transportation, reduced catches, withered / dead plants, reduced tourist arrivals]

The quality of education is decreasing [due to school holidays]

\section{Impact on Environment}

Peatlands shrink and heat rises

Forest products such as game animals and wood are of less economic value and are even extinct

Severe and transboundary haze

Dirty water [lots of burnt residue and acid release from peat material]

\section{Impact on Capital}

Garden / private land was burnt

House was burnt

Damage to public facilities (roads, bridges, houses of worship)

Land and water traffic accidents

Closing of public transportation route

Additional expenditure for drilling wells and / or land guard fees
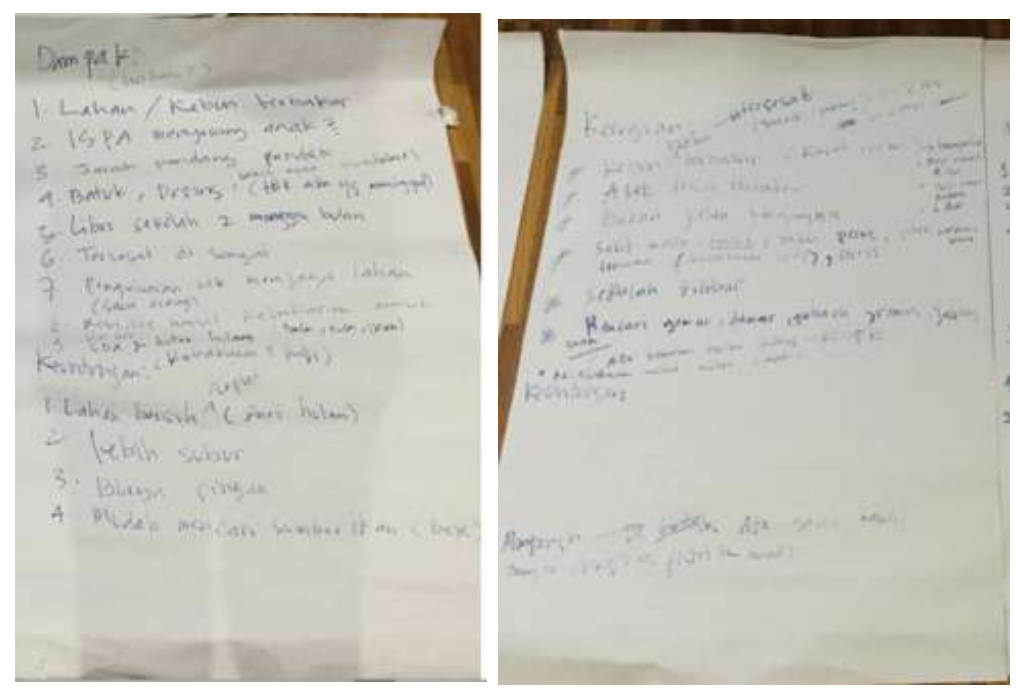

Figure 4. Raw Note Paper of FGD in Buntoi dan Tumbang Nusa Village, Pulang Pisau Regency on September 2018 


\section{CONCLUSION AND SUGGESTION}

\subsection{Conclusion}

The conclusions of this study are as follows:

1. The average category of hotspots for 12 years (2006 - 2018) showed that there were around 80 villages that were included in the medium to thevery high class which were spread in 4 (four) districts in Central Kalimantan.

2. Villages affected by fire in 2015 showed that there were 3 (three) main cause clusters namely natural, human and regulatory. Generally, these factors are a combination of two or more factors and/or sub-factors in a forest and land fire event.

3. The major impact clusters resulting from forest-land fires are on people, the environment and capital. As for the impacts experienced by humans in the short term generally such as health problems, the difficulty of livelihoods and the declining quality of education of school-age children.

\subsection{Suggestion}

For further research, it is suggested to do a detailed analysis with Root Cause Analysis (RCA) or Fishbone diagram to examine the root cause and effect of forestpeatland fires as well as the haze impact to choose the right options in fire reduction and climate change mitigation efforts.

\section{ACKNOWLEDGEMENT}

Great thanks to the chief of villages in Pulang Pisau Regency, Katingan Regency and Palangka Raya City, who had provided the stastitical data and village profile. This research was a collaboration project between UPT. Laboratorium Lahan GambutCIMTROP and CIFOR under Letter of Agreement (LoA) of Fiscal Year of 2018/2019 entitled "Enhancing ClimateResilient Livelihood In Boreal And Tropical High Carbon Forests And Peatlands", which supported by Ministry of Agriculture, Forestry and Fishery Japan (MAFF). Data collection in Taruna Jaya Village of Pulang Pisau Regency, Kereng Bangkirai Village and Kalampangan Village of Palangka Raya City was supported by Research Institute for Humanity and Nature (RIHN), Kyoto, Japan entitled "Action Research for the Peatland Restoration and Transdisciplinary Study for the Future of Peatland Society".

\section{REFERENCES}

Altares, P., Copo, A., Gabuyo, Y., Laddaran, A., Meija, L., Policarpio , I., . . . Yao, A. (2003). Elementary Statistics: A Modern Approach (1 ed.). Manila: Rex Book Store.

Anonymous. (8. May 2016). https://sampit.prokal.co/. Haettu 1.

Desember 2019 osoitteesta https://sampit.prokal.co/read/news/333 1-ribuan-hektare-lahan-perusahaan-dikawasan-gambut-kalteng-diambilalih-negara

Atwood, E., Englhart, S., Lorenz, E., Halle, W., Wiedemann, W., \& Siegert, F. (2016). Detection and Characterization of Low Temperature Peat Fires during the 2015 Fire Catastrophe in Indonesia Using a New High- Sensitivity Fire Monitoring Satellite Sensor (FireBird). PLOS ONE, 11(8), 1-24.

Barbara, B., Yulianti, N., \& Firdara, E. (2015). Knowledge, Attitude, and Practice (KAP) IKebakaran hutanlahandi Provinsi Kalimantan Tengah. J-SEA (Journal Socio Economics Agricultural(10), 1-9.

Carlson, K., Heilmayr, R., Gibbs, H., Noojipady, P., Burns, D., Mortonh, D., . . . Kremen, C. (2017). Effect of oil palm sustainability certification on deforestation and fire in Indonesia. PNAS, 1-6. 
DNPI, D. (2010). Indonesia's Greenhouse Gas Abatement Cost Curve. Jakarta: DNPI.

Endarwati. (2016). Analisis Data Titik Panas (Hotspot) dan Areal Kebakaran hutan-lahanTahun 2016. Jakarta: Direktorat Inventarisasi dan Pemantauan Sumber Daya Hutan, Ditjen Planologi Kehutanan dan Tata Lingkungan Kementerian Lingkungan Hidup dan Kehutanan.

Ferdinand, A. (2006). Metode Penelitian Manajemen: Pedoman Penelitian untuk skripsi, Tesis dan Disertai Ilmu Manajemen. Semarang: Universitas Diponegoro.

Giglio, L., Descloitres, J., Justice, C., \& Kaufman, Y. (2013). An Enhanced Contextual Fire Detection Algorithm for MODIS. Remote Sensing of Enviroment, 87, 273-282.

Hayasaka, H., \& Sepriando, A. (2018). Severe Air Pollution Due to Peat Fires During 2015 Super El Niño in Central Kalimantan, Indonesia. In K. Vadrevu, T. Ohara, \& C. Justice (Eds.), LandAtmospheric Research Applications in South and Southeast Asia (Vol. 195, pp. 129-142). Springer Remote Sensing/Photogrammetry Springer Cham.

Heil, A., Langmann, B., \& Aldrian, E. (2006). Indonesia Peat and Vegetation Fire Emissions: Study on Factors Influencing Large-Scale Smoke Haze Pollution using A Regional Atmospheric Chemistry Model. Mitigation and Adaptation Strategies for Global Change, 12, 113-133.

Hirschberger, P., 4con forestconsulting, \& www.forestconsulting.de. (2016). Forest Ablaze, Causes and Effects on Global Forest Fires. Berlin: WWF Deutschland.

Jua' rez-Orozco, S., Siebe, C., \& Ferna' ndez y Ferna 'ndez, D. (2017). Causes and Effects of Forest Fires in Tropical Rainforests: A Bibliometric Approach.
Tropical Conservation Science, 10, 114.

Koplitz , S., Mickley , L., Marlier, M., Buonocore, J., Kim , P., Liu, T., . . . Schwartz, J. (2016). Public health impacts of the severe haze in Equatorial Asia in September-October 2015: demonstration of a new framework for informing fire management strategies to reduce downwind smoke exposure. Environ Res Lett, 11(9).

Lestari, A., Rumantir, G., Tapper,, N., Saharjo, B., Usup, A., Graham, L., . . . Teguh, R. (2018). Analysing Causal Factors of Peatland Wild res: A Knowledge-based Approach. Melbourne: Pacific Asia Conference on Information Systems (PACIS 2018).

Limin, S., Takahashi, H., Usup, A., Hayasaka, H., Kamiya, M., \& Murao, N. (2007). Impacts of Haze in 2002 on Social Acivity and Human Health in Palangka Raya. Tropics 16, 275-282.

Loren, A., Ruslan, M., Yusran, F., \& Rianiwati, F. (2015). Analisis Faktor Penyebab Kebakaran Hutan-Lahan serta Upaya Pencegahan yang dilakukan Masyarakat di Kecamatan Basarang Kabupaten Kapuas Kalimantan Tengah. EnviroScienteae, 11, 1-9.

Marlier, M., Liu, T., Yu, K., Buonocore, J., Koplitz, S., DeFries, R., . . Myers, S. (2019). Fires, Smoke Exposure, and Public Health: An Integrative Framework to Maximize Health Benefits From Peatland Restoration. GeoHealth, 3, 178-189.

Priyono, A. (4. September 2019). https://www.borneonews.co.id/.

Haettu 20. Oktober 2019 osoitteesta https://www.borneonews.co.id/berita/ 136640-polda-kalimantan-tengahtangani-186-kasus-karhutla

Ramakreshnan, L, Aghamohammadi, N., Fong, CS., Bulgiba, A., Zaki, RA., Wong, LP., Sulaiman, NM. 2017. 
Haze and health impacts in ASEAN countries: a systematic review. Environmental Science and Pollution Research. https://doi.org/10.1007/s11356-0170860-y

Stockwell, C., Jayarathne, T., Cochrane, M., Ryan, K., Putra, E., Saharjo , B., ... . Stone, E. (2016). Field measurements of trace gases and aerosols emitted by peat fires in central Kalimantan, Indonesia, during the 2015 El Niño. Atmospheric Chemistry and Physics, 16, 11711-11732.

Sumarga, E. (2017). Spatial Indicators for Human Activities May Explain the 2015 Fire Hotspot Distribution in Central Kalimantan Indonesia. Tropical Conservation Science, 10, 19.

Uda, S., Hein, L., \& Atmoko, D. (2019). Assessing the health impacts of peatland fires: a case study for Central Kalimantan, Indonesia. Environmental Science and Pollution Research, 26(30), 31315-31327.

Van Mead, N. (2017, February 13). The Guardian. Retrieved from thegurdian.com:

https://www.theguardian.com/cities/da tablog/2017/feb/13/most-pollutedcities-world-listed-region

WBG, W. (2016). The Cost of Fire, An Economic Analysis of Indonesia's 2015 Fire Crisis. Jakarta: The World Bank.

Wooster, M., Gaveau, D., Salim, M., Zhang, T., Xu, W., Green, D., .. . Sepriando , A. (2018). New Tropical Peatland Gas and Particulate Emissions Factors Indicate 2015 Indonesian Fires Released Far More Particulate Matter (but Less Methane) than Current Inventories Imply. Remote Sensing, 131.

Yulianti , N., Hayasaka, H., \& Usup, A. (2012). Recent forest and Peat Fires Trends in Indonesia, The Latest Decade by MODIS Hotspot Data.
Global Environmental Research 16, 105-116.

Yulianti, N. (2011). The Health Effect of Smoke and Haze from Tropical Forest-Peat Fires. In Texbook for Summer School 2011 in Indonesia "Management Strategy of Tropical Peatland: Development and Conservation" (pp. 114-115). Bogor, Indonesia: Integrated Field Environmental Science Global Center of Excellent (IFES - GCOE) Indonesia Liason Office.

Yulianti, N. (2018). Pengenalan Bencana Kebakaran dan Kabut Asap Lintas Batas (Studi Kasus Eks Lahan Gambut Sejuta Hektar) (1 ed.). Bogor: IPB Press.

Yulianti, N., \& Hayasaka, H. (2013). Recent Active Fire under El Niño Conditions in Kalimantan, Indonesia. American Journal of Plans Science, 4, 685-696.

Yustiawati, Sazawa, K., Syawal, M., Kuramitz, H., Saito, T., Hosokawa, T., Tanaka, S. (2016). Peat Fire Impact on Water Quality and Organic Matter in Peat Soil. In M. Osaki , \& N. Tsuji (Eds.), Tropical Peatland Ecosystems (pp. 281-296). Tokyo: Springer.

Yulianti, N., Kusin, K., Naito, D., Kawasaki, M., \& Kozan, O. (2019). The Linkage of El Niño -induced Peat Fire and Its Relation to Current Haze Condition in Central Kalimantan. Banjarmasin: The International Symposium on Wetland Environmental Management (ISWEM 2019). Banjarmasin, 4-6 November 2019. 